\title{
A PROTEOMIC AND TARGETED METABOLOMIC APPROACH TO INVESTIGATE CHANGES IN Stylosanthes scabra VOGEL PLANTS IN RELATION TO NaCI SALINITY
}

\author{
PRERNA AGARWAL ${ }^{a 1}$ AND K.A. VARSHNEY

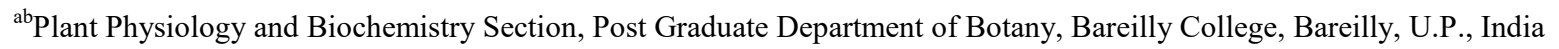

\begin{abstract}
A pot culture was designed to examine the role of accumulated proline, choline and glycine-betaine in Stylosanthes scabra Vogel under saline conditions. The results indicated that proline was affected adversely by salinity stress, whereas glycine-betaine and choline contents were found to increase. Salinity caused decrease in proline contents might be due to disturbance in amino acid metabolism.
\end{abstract}

KEYWORDS: Proline, Choline, Glycine-Betaine, $\mathrm{NaCl}$ Salinity

Salinity is regarded as one of the important abiotic stresses that limits yield in various crops. It is estimated that about 2 billion ha of land that were once biologically productive are now degraded (Anon, 1992). The alarmingly rising human population has created an ever-expanding demand for food, fuel wood, fibre and fodder crops putting an intolerable pressure on land, water and other resources. Thus, species of the tropical pasture legume, Stylosanthes have shown promise as pasture and forage crops in the tropical and sub- tropical regions in Australia, Africa, South-east Asia and India.

During osmotic stress, plant induce processes that regulate the osmotic adjustment and maintain sufficient cell turgor for growth to proceed (Zimmermann, 1978). Since adjustment requires the control of intracellular inorganic ions in the cytoplasm through accumulation of organic compounds compartmented mainly in the cytoplasm (Jeschke et al., 1986) (Binzel et al., 1988) (Bohnert et al., 1995). These organic solutes termed as osmolytes, compatible solutes or osmoprotectants, are non- toxic molecules having relatively low molecular weight that raise osmotic pressure and protect some macromolecular structures against denaturation (Timasheff, 1992) (Bourot et al., 2000).

Decrease in proline contents due to salinity has been recorded earlier by Rodriguez et al., (1997) Samia ElSayed, (2008) Sidari et al., (2008). However, most of the studies report a significant increase in proline contents. Salinity induced decrease in proline contents as observed in the present study, might be due to a disturbance in amino acid metabolism. But choline and glycine-betaine contents are significantly increased on exposure to salt stress. Our study hardly advocates for any role of proline in imparting tolerance to salinity in Stylo plants. This is because Stylosanthes scabra despite having the highest levels of choline in its tissues, is the most susceptible species to salinity treatment. For instance, Jacob et al., (1999) and Jackson and Seppelt (1995) did not find any accumulation of proline in Prasiola plants after different exposure to salt. Glycine-betaine is the predominant osmoprotectant and could be used as a reliable index of stress tolerance in Stylos plants.

\section{MATERIALS AND METHODS}

The certified seeds of Stylosanthes were procured from IGFRI, Jhansi (India). They were surface sterilized with $1 \% \mathrm{HgCl}_{2}$ for 15 minutes and thoroughly rinsed with distilled water. Seeds were placed in pots to germinate and were transplanted. Plants from each pot were harvested randomly at leafy stage (64 DAS) and at flowering stage (124 DAS). $\mathrm{NaCl}$ was added and mixed so as to fix the ECe of soil saturation extract at $4 \mathrm{mScm}^{-1}$. Ordinary garden soil was used as control $\left(1.2 \mathrm{mScm}^{-1}\right)$. The treatments were applied at fortnightly intervals.

Proline contents were estimated by the method of Bates et al., (1973). 0.5g of sample was homogenized in a blender with $10 \mathrm{ml}$ of $3 \%$ aqueous sulphosalicyclic acid and centrifuged at $10,000 \mathrm{~g}$. $2 \mathrm{ml}$ of filtrate was reacted with $2 \mathrm{ml}$ of acid ninhydrin solution and $2 \mathrm{ml}$ of glacial acetic acid was boiled for 1 hour at $100^{\circ} \mathrm{C}$,in a water bath. The reaction was stopped in an ice bath and then $4 \mathrm{ml}$ of toluene was added. The absorbance was read at $520 \mathrm{~nm}$ on a UV visible spectrophotometer (Shimadzu-1601). The protein content was expressed as $\mu$ mole $\mathrm{g}^{-1}$ fresh weight. The data were analysed by analysis of variance (ANOVA) method.

\footnotetext{
${ }^{1}$ Corresponding author
} 
Choline and glycine-betaine were determined by non-specific but per-iodide spectrophotometric method (Speed and Richardson, 1968) and by Direct reflectance Densitometry as described by Radecka et al. (1971) at CDRI, Lucknow (India). The proline and glycine-betaine contents were expressed as $\mu \mathrm{g} \mathrm{g}^{-1}$ fresh weight.

\section{RESULTS AND DISCUSSION}

Under osmotic stress conditions various plants accumulate Proline and/or betaines (Wyn Jones and Storey, 1981). Glycine-betaine plays a major role in conferring resistance to drought, salinity and cold stress (Wyn Jones and Storey, 1981) (Zao et al., 1992) (Naidu et al., 1996). The present study reveals that salt stress brought about a marked depletion in protein content, whereas choline and glycine-betaine increased considerably.

The data tabulated in table revealed that under the influence of salinity, plants depicted $15.87 \%$ decline in proline content over control at leafy stage. Likewise, it declined $24.15 \%$ over control at flowering stage. The values were calculated to be $365.15 \mu$ mole g $^{-1}$ in control plants and $307.20 \mu$ mole g $^{-1}$ in treated plants at leafy stage and 253.20 $\mu$ mole $\mathrm{g}^{-1}$ in control plants and $192.05 \mu$ mole $\mathrm{g}^{-1}$ in treated plants at flowering stage.

Table : Proline, choline and glycine-betaine contents of Stylos plants under artificial salinization

\begin{tabular}{|c|c|c|c|c|}
\hline Sl. No. & Parameters & Growth stages & Untreated $\left(\mathbf{1 . 2} \mathbf{~ m S c m}^{-\mathbf{1}}\right)$ & Treated $\left.\mathbf{( 4 . 0 ~} \mathbf{~ m S c m}^{-\mathbf{1}}\right)$ \\
\hline \multirow{2}{*}{1.} & \multirow{2}{*}{ Proline $\left(\mu \mathrm{mol} \mathrm{g}^{-1}\right)$} & $\mathrm{I}^{*}$ & 365.15 & 307.20 \\
\cline { 3 - 5 } & \multirow{2}{*}{2.} & $\mathrm{II}^{*}$ & 253.20 & 192.05 \\
\hline \multirow{2}{*}{3.} & \multirow{2}{*}{ Choline $\left(\mu \mathrm{g} \mathrm{g}^{-1}\right)$} & $\mathrm{I}^{*}$ & 22.20 & 30.60 \\
\cline { 3 - 5 } & \multirow{2}{*}{ Glycine-betaine $\left(\mu \mathrm{g} \mathrm{g}^{-1}\right)$} & $\mathrm{II}^{*}$ & 24.43 & 31.93 \\
\cline { 3 - 5 } & & $\mathrm{II}^{*}$ & 34.87 & 41.17 \\
\hline
\end{tabular}

*Leafy stage; **Flowering stage

\begin{tabular}{|l|c|c|c|}
\hline For proline & 7.853 & 7.853 & 11.106 \\
\hline SEm \pm & 23.669 & 23.669 & 33.474 \\
\hline CD at 5\% P & 0.3800 & 0.3800 & 0.537 \\
\hline For choline & 1.146 & 1.146 & 1.619 \\
\hline SEm \pm & CD at 5\% P & 0.408 & 0.577 \\
\hline For glycine-betaine & 0.408 & 1.230 & 1.740 \\
\hline SEm \pm & 1.230 &
\end{tabular}

The data portrayed in table indicated that choline content is significantly greater in treated plants $(30.60 \mu \mathrm{g}$ $\left.\mathrm{g}^{-1}\right)$ over control plants $\left(22.20 \mu \mathrm{g} \mathrm{g}^{-1}\right)$ at leafy stage. It was increased by $37.84 \%$ over control. Similarly, at flowering stage, it increased by $31.93 \mu \mathrm{g} \mathrm{g}^{-1}$ in treated plants over control plants showing $24.43 \mu \mathrm{g} \mathrm{g}^{-1}$. The percentage increment was calculated to be $30.69 \%$.

The glycine-betaine content also showed marked increase under salinization. At leafy stage, it increased by $39.07 \mu \mathrm{g} \mathrm{g}^{-1}$ over control i.e. $34.87 \mu \mathrm{g} \mathrm{g}^{-1}$.Likewise, at flowering stage, it increased by $41.17 \mu \mathrm{g} \mathrm{g}^{-1}$ over control i.e. $36.20 \mu \mathrm{g} \mathrm{g}^{-1}$. The percentage increment was calculated to be $12.04 \%$ and $13.73 \%$ at leafy and flowering stage respectively.
Similar findings have been recorded earlier by Rodriguez et al. (1997) Samia El-Sayed Saffan (2008) Sidari et al., (2008) in respect of proline content. Salinity induced decrease in proline contents as observed might be due to a disturbances in amino acid metabolism. Role of proline in Stylosanthes scabra may be investigated further. There are reports that accumulation of proline in response to salinity is not mandatory.

The glycine-betaine was found to accumulate more than choline. This may be due to the fact that accumulate choline is catabolized rapidly after induction of salt stress whereas the accumulated glycine-betaine remains unmetabolised in the tissues. These findings are similar to 
those of Ahmad and Wyn Jones, 1979; (Browman and Rohringer, 1970) (Hanson et al. 1978).

A general biosynthetic solute leading to the formation of glycine-betaine is a two-step oxidation of choline catalysed by choline mono-oxygenase and betaine aldehyde dehydrogenase (BADH) in chloroplasts (Brouquisse et al., 1989) (Papageorgiov et al., 1991) (Rhodes and Hanson, 1993). Our studies on both treated and control plants revealed accumulation of serine besides choline and glycine-betaine which reflects that the ultimate precursor of betaine might be an amino acid serine.

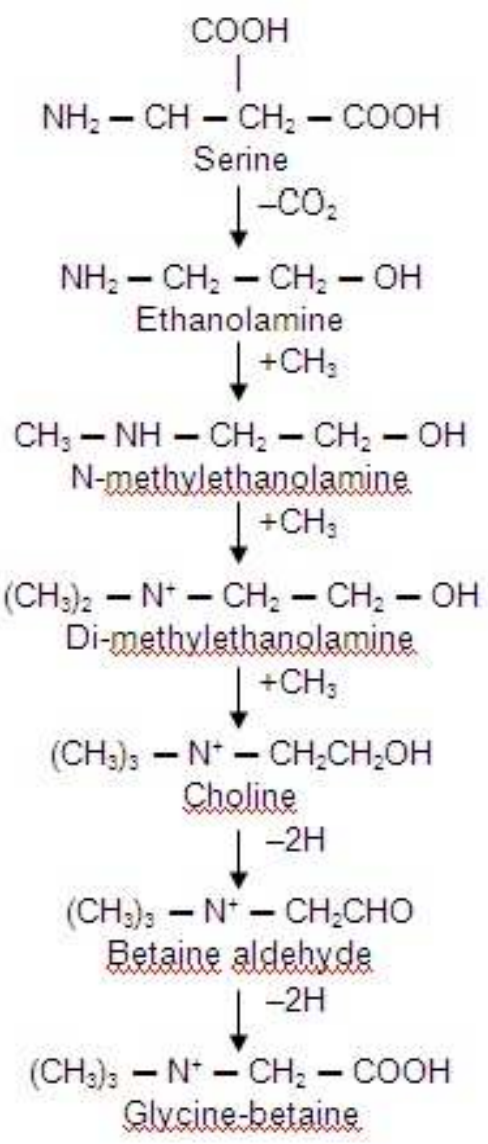

Pathway of glycine-betaine synthesis

Therefore, synthesis of glycine-betaine probably involves the decarboxylation of serine and sequential methylation of ethanol amine to choline followed by a two step oxidation of choline to glycine-betaine. The activity of betaine aldehyde dehydrogenase (BADH), a terminal enzyme of the glycine-betaine biosynthetic pathway exhibited significant inclination in a stylos plants subjected to stress of $\mathrm{NaCl}$ salt.
This modest increase in the activity of betaine aldehyde dehydrogenase can be attributed to increased levels of protein and transcripts for this enzyme (Weretilnyk and Hanson, 1989, 1990) (McCue and Hanson, 1992).

Hence proline, choline and glycine-betaine contents can be considered as one of the most physiological criteria for assessing combatment of osmotic stress in stylos plants.

\section{ACKNOWLEDGEMENTS}

Authors are thankful to Dr. R.B.R. Yadava and Dr. Rajeev Tiwari, Senior Scientists, IGFRI, Jhansi for providing Stylos seed samples and valuable suggestions for this work.

\section{REFERENCES}

Ahmad N. and Wyn Jones R.G., 1979. Glycine-betaine, proline and inorganic ion levels in barley seedlings following transient stress. Plant Sci. Letl., 15: 231237.

Anon, 1992. Joint Forest Management Regulations Update. Society for Promotion of Wastelands Development: New Delhi, India.

Bates L.S., Waldern R.P. and Teare I.D., 1973. Rapid determination of free proline for water stress studies. Plant Soil, 39: 205-207.

Binzel M.L., Hess F.D., Bressan R.A. and Hasegava P.M., 1988. Intracellular compartmentation of ions in salt adapted tobacco cells. Plant Physiol., 86: $607-$ 614.

Bohnert H.J., Nelson D.E. and Jensen R.G., 1995. Adaptation to environmental stresses. Plant Cell, 7: 1099-1111.

Bourot S., Sire O., Trautwetter A., Touze T., Wu L.F., Blanco C. and Bernard T., 2000. Glycine-betaine assisted protein folding in a lys A mutant of Escherichia coli. J. Biol. Chem., 275: 1050-1056.

Brouquisse R., Weigel P., Rhodes D., Yowm C.F. and Hanson A.D., 1989. Evidence for a ferredoxin dependent choline monooxygenase from spinach chloroplast stroma. Plant Physiol., 90: 322-329. 
Browman M.S. and Rohringer R.O., 1970. Formate metabolism and betaine formation in healthy and rust infected wheat. Can. J. Bot., 48: 803-811.

Hanson A.D., Nelson C.E. and Ladyman J.A.R., 1978. Betaine accumulation in water-stressed barely leaves (Abstr.). Plant Physiol., 61(Suppl.): 81.

Jackson A.F. and Seppelt R.D., 1995. The accumulation of proline in Prasiola crispa during winter in Antarctica. Plant Physiol., 94: 25-30.

Jacob A., Kirst G.O., Wiencke C. and Lehmann H., 1999. Physiological responses of the Antarctic green alga Prasiola crispa spp. antarctica to salinity stress. J. Plant Physiol., 139: 57-62.

Jeschke D., Pate J.S. and Atkins G.A., 1986. Effects of $\mathrm{NaCl}$ salinity on growth, development, ion transport and ion storage in white lupin (Lupinus albus L. cv. Ultra). J. Plant Physiol., 124: 257-274.

McCue K.F. and Hanson A.D., 1992. Effect of soil salinity on the expression of betaine aldehyde dehydrogenase in leaves; investigation of hydraulic, ionic and biochemical signals. Australian Journal of Plant Physiology, 19(5): $555-564$.

Naidu B.P., Thumna B.R., Camerson D.F. and Hacker J.B., 1996. A biochemical approach to improving survival of salt or drought stressed plants. Tropical Grasslands, 30: 141.

Papageorgiov G.C., Fujimura Y. and Murata N., 1991. Protection of the oxygen evolving photosystem II complex by glycine-betaine. Biochemica et Biophysica Acta., 105: 361-366.

Radecka C., Genest K. and Hughes D.W., 1971. Quaternary ammonium compounds in plants in relation to salt resistance. Phytochem., 16: 447-453.

Rhodes D. and Hanson A.D., 1993. Quaternary ammonium and teritary sulphonium compounds in higher plants. Annual Review of Plant Physiology, Plant Molecular Biology, 44: 357-384.

Rodriguez H.G., Roberts G.K.M., Jordan W.R. and Drew M.C., 1997. Growth, water relations, and accumulation of organic and inorganic solutes in roots of maize seedlings during salt stress. Plant Physiology, 113: 881-893.

Samia El-Sayed S., 2008. Effect of salinity and osmotic stresses on some economic plants. Research J. Agric. and Biol. Sci., 4(2): 159-166.

Sidari M., Santonoceto C., Anabtasi U., Preiti G. and Muscolo A., 2008. Variations in four genotypes of lentil under $\mathrm{NaCl}$ salinity stress. American Journal of Agricultural and Biological Science, 3(1): 410416.

Speed D. and Richardson M., 1968. J. Chromatg., 35: 497. (C.F. Storey, R. and Wyn Jones, R.G. 1977). Quaternary ammonium compound in plant in relation to salt resistance. Phytochem., 16: 447 453.

Timasheff S.N., 1992. A physiochemical basis for selection of osmolytes by nature. In G.N. Somero, C.B. Osmond, C.L. Bolis, eds, Water and Life. Springer-Verlag, Berlin. pp. 70-84.

Weretilnyk E.A. and Hanson A.D., 1990. Molecular cloning of a betaine-aldehyde dehydrogenase, an enzyme implicated to adaptation to salinity and drought. Proc. Natl. Acad. Soil Sci., 27: 45- 49.

Weretilnyk E.A., Bednarek S., McCue K.F., Rhodes D. and Hanson A.D., 1989. Comparative biochemical and immunological studies of the glycine-betaine synthesis pathway in diverse families of dicotyledons. Planta, 178: 342-352.

Wyn Jones R.G. and Storey R., 1981. Betaines: In 'The Physiology and Biochemistry of Drought Resistance in Plants (eds): Paleg, L.G. and Aspinall, D. (Academic Press, Sydney): pp. 171204.

Zao Y., Aspinall D. and Paleg L.G., 1992. Protection of membrane integrity in Medicago sativa L. against the effects of freezing. Journal of Plant Physiology, 140: 541-543.

Zimmermann U., 1978. Physics of turgor and osmoregulation. Annu. Rev. Plant Physiol., 29: 121-148. 